\title{
UJI AKTIVITAS ANTIPIRETIK EKSTRAK DAUN SISIK NAGA(Pyrrosia piloselloides (L.) M.G. Price) TERHADAP TIKUS PUTIH (Rattus norvegicus) JANTAN GALUR WISTAR YANG DIINDUKSI PEPTON 5\%
}

\author{
Ratna Widyasari $^{* 1)}$, Dina Yuspitasari ${ }^{2}$, Fadli $^{3)}$, Athiah Masykuroh $^{4)}$, Winda Tahuhiddah ${ }^{5)}$ \\ ${ }^{1,2}$ Akademi Farmasi Yarsi Pontianak \\ Email: Sharee_300302@yahoo.co.id
}

\begin{abstract}
INTISARI
Demam adalah keadaan ketika suhu tubuh meningkat melebihi suhu tubuh normal. Demam terjadi karena pelepasan pirogen dari dalam leukosit yang sebelumnya telah terangsang oleh pirogen eksogen yang dapat berasal dari mikroorganisme atau merupakan suatu hasil reaksi imunologik yang tidak berdasarkan suatu infeksi. Sementara itu, banyak negara telah mengembangkan pengobatan menggunakan herbal. Salah satu usaha yang dilakukan adalah dengan penggunaan obat tradisional. Penelitian ini bertujuan untuk membuktikan bahwa daun Sisik Naga (Pyrrosia piloselloides (L.) M.G Price) dengan konsentrasi 0,062\%, 0,125\% dan 0,25\% memiliki aktivitas antipiretik dengan menggunakan penginduksi demam Pepton 5\%. Penelitian ini merupakan penelitian eksperimental dengan Rancang Acak Lengkap (RAL). Pengukuran suhu rektal tikus menggunakan termometer infra red. Hewan uji dibagi menjadi 5 kelompok yaitu kelompok kontrol negatif (suspensi Na-CMC 1\%), kelompok kontrol positif (suspensi parasetamol) dan kelompok uji yaitu pemberian ekstrak daun sisik naga $0,062 \%, 0,125 \%$ dan $0,25 \%$. Data yang diperoleh dianalisis dengan menggunakan uji anova dan uji LSD (Least Significant Different). Hasil dari penelitian ini bahwa ekstrak daun sisik naga (Pyrrosia piloselloides (L.) M.G Price) konsentrasi $0,25 \%$ mempunyai aktivitas antipiretik pada tikus putih (Rattus norvegicus) jantan galur wistar.
\end{abstract}

Kata kunci: Antipiretik, Daun Sisik Naga (Pyrrosia piloselloides (L.) M.G Price), Pepton 5\%

\begin{abstract}
A fever is a condition when the body temperature rises beyond the normal body temperature. Fever occurs due to the release of pyrogytes from within leukocytes that have previously been stimulated by exogenous pyrogens that may originate from microorganisms or are a result of immunologic reactions that are not based on an infection. Meanwhile, many countries have developed treatments using herbs. One of the efforts done is with the use of traditional medicine. This study aims to prove that the leaves of the Dragon Scales (Pyrrosia piloselloides (L.) M.G Price) with concentrations of $0.062 \%, 0.125 \%$ and $0.25 \%$ have antipyretic activity using Pepton fever induction 5\%. This research is an experimental research with Completely Random Design (RAL). Rectal temperature measurements of mice using infra red thermometer. Test animals were divided into 5 groups: negative control group (1\% Na-CMC suspension), positive control group (paracetamol suspension) and the test group were $0.062 \%, 0.125 \%$ and $0.25 \%$. The data obtained were analyzed using anova test and LSD (Least Significant Different) test. The results of this study showed that the extract of leaf scales (Pyrrosia piloselloides (L.) M.G Price) concentrations of $0.25 \%$ had antipyretic activity in white rats (Rattus norvegicus) male wistar strain.
\end{abstract}

Keywords: Antipyretics, Leaf Scales Dragon (Pyrrosia piloselloides (L.) M.G Price), Pepton 5\% 
Corresponding author:

Ratna Widyasari

Akademi Farmasi Yarsi Pontianak

JL. Panglima A'im No. 2 Pontianak

Email: Sharee_300302@yahoo.co.id

\section{PENDAHULUAN}

Demam adalah keadaan ketika suhu tubuh meningkat melebihi suhu tubuh normal (Tamsuri, 2007). Suhu tubuh normal berkisar antara $36,5^{\circ} \mathrm{C}-37,2^{\circ} \mathrm{C}$. Suhu subnormal di bawah $36^{\circ} \mathrm{C}$. Demam diartikan suhu tubuh diatas $37,2^{\circ} \mathrm{C}$ (Hariyanto, 1995). Demam juga merupakan suatu regulasi panas pada suatu tingkat suhu yang lebih tinggi dan juga gejala yang menyertai hampir semua infeksi, tetapi juga terdapat pada penyakit - penyakit lain seperti pada beberapa bentuk tumor (Mutschler, 1986).

Demam dapat terjadi pada usia anak - anak maupun orang dewasa, yang pastinya demam ini sangat mengganggu karena suhu tubuh meningkat. Masyarakat biasanya menggunakan obat obat antipiretik untuk dapat menurunkan suhu tubuh. Obat - obat antipiretik yang sering digunakan masyarakat untuk mengobati demam yatu parasetamol, asetosal dan sejenisnya. Obat - obat sintetik memiliki efek samping jika penggunaannya dalam jangka waktu yang panjang. Pengobatan secara herbal dengan menggunakan tanaman obat masih kurang diperhatikan. Salah satunya yang dapat dimanfaatkan adalah daun sisik naga, pemanfaatan daun sisik naga di Indonesia masih belum banyak, terutama sebagai antipiretik. Tanaman sisik naga (Pyrrosia piloselloides (L.) M.G Price.) mengandung minyak atsiri, sterol (triterpen), fenol, flavonoid, tanin, saponin dan gula (Hariana, 2006).

Senyawa kimia yang memiliki efek antipiretik adalah flavonoid, flavonoid merupakan salah satu senyawa yang dapat menghambat prostaglandin, proteinkinase, monoaminoksidase, DNA polymerase dan siklooksigenase (Kohli et. al., 2005). sehingga demam menjadi turun (Rakayudha, 2010).

Tanaman sisik naga (Pyrrosia piloselloides (L.) M.G Price.) digunakan masyarakat sebagai obat untuk menyembuhkan radang gusi, sariawan, pendarahan, rematik pada jaringan lunak, TBC paru - paru disertai batuk darah, dan kanker payudara (Hariana, 2006). Sisik naga dapat juga digunakan untuk pengobatan gondongan (Parotitis), sakit kuning (Jaundice), sakit perut, sembelit, keputihan, pemakaian luar untuk penyakit kulit, seperti kudis dan kurap (Dalimarta, 2002). Namun sampai saat ini belum ada penelitian terhadap potensi tanaman sisik naga sebagai antipiretik. Berdasarkan uraian diatas peneliti ingin melakukan penelitian Uji Aktivitas Antipiretik Ekstrak Daun Sisik Naga (Pyrrosia piloselloides (L.) M.G Price) Terhadap Tikus Putih (Rattus norvegicus) Jantan Galur Wistar Yang Diinduksi Pepton 5\%.

\section{METODE PENELITIAN}

Bahan penelitian

Bahan - bahan yang digunakan dalam penelitian ini diantaranya, daun sisik naga (Pyrrosia piloselloides (L.) M.G Price.), Etanol 96\%, aquadest, Na-CMC 1\%, parasetamol serbuk, Pepton $5 \%$.

Alat Penelitian

Alat - alat yang digunakan dalam penelitian ini diantaranya kandang tikus, tempat air minum dan makanan hewan, handscoon, gelas beker $100 \mathrm{~mL}$, gelas beker $50 \mathrm{~mL}$, gelas beker 1000 $\mathrm{mL}$, gelas ukur $100 \mathrm{~mL}$, gelas ukur $1000 \mathrm{~mL}$, labu ukur $50 \mathrm{~mL}$, timbangan analitik, neraca ohaus, batang pengaduk kayu, sendok stainless, spuit $1 \mathrm{~mL}$, spuit $5 \mathrm{~mL}$, sonde oral, stopwatch, pisau stainless, bejana maserasi, blender, kertas saring 30 x $30 \mathrm{~cm}$, aluminium foil, vacuum rotary evaporator, oven dry cabinet, mortir, stemper, hot plate, termometer infra red. 


\section{JALANNYA PENELITIAN}

1. Aklimatisasi Hewan Uji

Tikus yang digunakan adalah tikus putih jantan galur wistar (Rattus norvegicus) dengan berat badan 150 - 200gram dan umur $2-3$ bulan. Tikus diadaptasikan dalam kondisi yang sama, jauh dari kebisingan dan dihindarkan dari stress. Fase aklimatisasi berjalan selama satu minggu di kandang hewan yang sudah diberi sekam, yang berfungsi untuk menyerap kotoran tikus (Ibrahim.,dkk, 2014). Masing - masing kandang berisi 5 ekor tikus. Hewan uji dipuasakan 18 jam namun tetap diberi minum ad libitum. Kandang di tempatkan di kandang hewan AKFAR YARSI Pontianak.

2. Pembuatan Ekstrak Daun Sisik Naga (Pyrrosia piloselloides (L.) M.G Price.)

Daun sisik naga (Pyrrosia piloselloides (L.) M.G Price.) diambil di jalan Raya Sungai Kakap, Desa Pal IX, Kubu Raya, Kalimantan Barat. Kemudian dilakukan determinasi di Lembaga Ilmu Pengetahuan Indonesia (LIPI) Bogor. Sampel tanaman sisik naga yang telah dipetik, dipisahkan bagian daunnya kemudian dicuci dengan air hingga bersih dan ditiriskan. Kemudian daun sisik naga di potong kecil - kecil dan dibiarkan kering tanpa kena sinar matahari langsung, pengeringan dilanjutkan dengan menggunakan oven pada suhu tidak melebihi $50^{\circ} \mathrm{C}$. Setelah kering kemudian dihaluskan dengan menggunakan blender dan diayak hingga menjadi serbuk.

3. Pembuatan Suspensi Na-CMC 1\%

Suspensi $\mathrm{Na}$ - CMC dibuat dengan cara ditimbang 1 gram $\mathrm{Na}-\mathrm{CMC}$, kemudian dimasukkan sedikit demi sedikit ke dalam mortir yang berisi $50 \mathrm{~mL}$ akuades panas (suhu $70^{\circ} \mathrm{C}$ ) dan didiamkan selama 30 menit hingga diperoleh massa yang transparan, diaduk lalu diencerkan dengan akuades hingga $100 \mathrm{~mL}$ (Anief, 1995).

4. Pembuatan Suspensi Parasetamol

Pembuatannya yaitu dengan parasetamol serbuk sebanyak $500 \mathrm{mg}$, sesuai dengan dosis lazim untuk manusia yang dikonversi ke tikus percobaan, kemudian digerus dan ditimbang serbuk sebanyak $360 \mathrm{mg}$. Kemudian dimasukkan dalam mortir dan ditambahkan dengan suspensi $\mathrm{Na}$ - CMC sedikit demi sedikit sambil digerus hingga homogen, Lalu dimasukkan dalam labu ukur $50 \mathrm{~mL}$. Kemudian volumenya dicukupkan hingga $50 \mathrm{~mL}$ dengan suspensi $\mathrm{Na}$ - CMC.

5. Desain Pengamatan Efek Antipiretik

Sebanyak 25 ekor hewan uji dibagi menjadi 5 kelompok (masing - masing kelompok terdiri dari 5 ekor tikus putih), sebelum dilakukan pengujian hewan dipuasakan selama 18 jam tetapi tetap diberi minum ad libitum. Dilakukan pengukuran suhu awal dengan menggunakan termometer infra red pada rektal tikus. Semua hewan uji diinduksi demam dengan pepton 5\% sebanyak $3 \mathrm{~mL} / \mathrm{ekor}$ secara subkutan. 1 jam setelah pemberian penginduksi, dilakukan pengukuran kembali suhu tubuh tikus. Jika terjadi peningkatan suhu tubuh lebih dari atau sama dengan $0,6^{\circ} \mathrm{C}$ dari suhu awal maka tikus dikatakan demam (Depkes, 1995). Kemudian tiap kelompok diberikan dosis secara oral. Kelompok 1 sebagai kontrol negatif diberi suspensi $\mathrm{Na}-\mathrm{CMC} 1 \%$, kelompok 2 sebagai kontrol positif diberi suspensi parasetamol, kelompok 3 diberi suspensi ekstrak daun sisik naga 0,062\%, kelompok 4 diberi suspensi ekstrak daun sisik naga $0,125 \%$, dan kelompok 5 diberi suspensi ekstrak daun sisik naga 0,25\%. Dilakukan pengukuran kembali selama 4 jam dengan interval 30 menit (Ibrahim., et al, 2014). 


\section{ANALISIS DATA}

Dari data yang diperoleh, dilakukan uji homogenitas dan uji normalitas dengan Kolmogorov - Smirnov test, jika hasilnya terdistribusi normal dilanjutkan dengan uji ANOVA dengan taraf kepercayaan $95 \%$ (Styawan, 2015).

\section{Hasil dan Pembahasan}

Tanaman yang digunakan adalah daun sisik naga dimana hasil determinasi yang dilakukan di Lembaga Ilmu Pengetahuan Indonesia (LIPI) tanaman ini berjenis Pyrrosia piloselloides (L.) M.G. Prince. Sebelumnya dilakukan pembuatan simplisia kering daun sisik naga dengan cara memisahkan antara batang/akar dan daun. Proses ini yang diambil adalah daunnya. Didapatkan hasil rendemen simplisia yaitu 8,126\%. Selanjutnya adalah pembuatan serbuk simplisia dengan cara menghaluskan simplisia dengan blender. Kemudian dimaserasi dengan etanol 96\% sebanyak $3250 \mathrm{ml}$ selama 3 hari. Disaring dan hasil filtrat selama 3 hari sebesar 2,5 liter. Dilakukan pemekatan dengan rotary evaporator didapatkan hasil sebanyak 43,77 gram. Rendemen yang dihasilkan oleh ekstrak etanol daun sisik naga adalah 11,16\%.

Dari hasil penelitian didapatkan data rata - rata hasil perhitungan suhu rektal tikus putih (Rattus norvegicus) jantan galur wistar sebelum dan sesudah pemberian penginduksi demam pepton $5 \%$ dapat dilihat pada tabel I.

Tabel I. Rata-rata Suhu Rektal Tikus

\begin{tabular}{cccccccccc}
\hline \multicolumn{1}{c}{$\begin{array}{c}\text { Suhu } \\
\text { awal }\end{array}$} & $\mathbf{0}^{\prime}$ & $\mathbf{3 0}$ & $\mathbf{6 0}$ & $\mathbf{9 0}^{\prime}$ & $\mathbf{1 2 0}$ & $\mathbf{1 5 0}$ & $\mathbf{1 8 0}$ & $\mathbf{2 1 0}$ & $\mathbf{2 4 0}$ \\
\hline $37,3 \pm 0$ & $37,76 \pm 0,08$ & $37,3 \pm 0,24$ & $37,04 \pm 0,11$ & $37,0 \pm 0,07$ & $36,92 \pm 0,04$ & $36,9 \pm 0$ & $36,98 \pm 0,04$ & $36,96 \pm 0,05$ & $36,98 \pm 0,04$ \\
\hline $37,12 \pm 0,05$ & $37,88 \pm 0,13$ & $37,8 \pm 0,14$ & $37,68 \pm 0,04$ & $37,7 \pm 0$ & $37,74 \pm 0,25$ & $37,56 \pm 0,13$ & $37,66 \pm 0,08$ & $37,62 \pm 0,13$ & $37,22 \pm 0,05$ \\
\hline $37,15 \pm 0,05$ & $37,64 \pm 0,05$ & $37,1 \pm 0,07$ & $37,18 \pm 0,10$ & $37,14 \pm 0,15$ & $37,0 \pm 0,07$ & $36,96 \pm 0,05$ & $36,92 \pm 0,04$ & $36,98 \pm 0,04$ & $36,98 \pm 0,04$ \\
\hline $37,14 \pm 0,05$ & $37,7 \pm 0$ & $37,18 \pm 0,21$ & $37,14 \pm 0,05$ & $37,02 \pm 0,08$ & $37,0 \pm 0,07$ & $36,98 \pm 0,04$ & $36,9 \pm 0$ & $36,98 \pm 0,04$ & $37,0 \pm 0$ \\
\hline $37,34 \pm 0,20$ & $38 \pm 0,08$ & $37,36 \pm 0,28$ & $37,28 \pm 0,25$ & $37,08 \pm 0,13$ & $37,02 \pm 0,04$ & $36,96 \pm 0,54$ & $36,98 \pm 0,04$ & $36,94 \pm 0,05$ & $36,96 \pm 0,05$
\end{tabular}

Keterangan:

$\begin{array}{ll}\mathrm{K}+ & \text { : Tikus demam mendapatkan suspensi parasetamol } \\ \mathrm{K}- & \text { : Tikus demam mendapatkan suspensi Na-CMC } 1 \% \\ \text { E } 1 & \text { : Tikus demam mendapatkan suspensi ekstrak sisik naga } 0,062 \% \\ \text { E } 2 & \text { : Tikus demam mendapatkan suspensi ekstrak sisik naga } 0,125 \% \\ \text { E } 3 & \text { : Tikus demam mendapatkan suspensi ekstrak sisik naga } 0,25 \%\end{array}$

Berdasarkan tabel I diketahui bahwa kisaran rata - rata suhu normal tikus sebelum diberi perlakuan adalah berkisar antara 37,12 - 37,34 ${ }^{\circ} \mathrm{C}$. Sedangkan suhu rektal tikus setelah pemberian pepton 5\% sebanyak $3 \mathrm{~mL}$ /ekor secara subkutan berkisar $37,64-38{ }^{\circ} \mathrm{C}$. Sebelumnya telah dilakukan uji pendahuluan pada pemberian pepton $5 \%$ dengan berbagai volume, diantaranya adalah volume $2 \mathrm{~mL}, 3 \mathrm{~mL}, 4 \mathrm{~mL}$, dan $5 \mathrm{~mL}$ per masing-masing tikus. Hasil yang didapat adalah pada pemberian $2 \mathrm{~mL}$ pepton $5 \%$ interval suhu awal dengan suhu setelah pemberian adalah $0,4^{\circ} \mathrm{C}$, pemberian $3 \mathrm{~mL}$ pepton $5 \%$ adalah $0,7^{\circ} \mathrm{C}$, pemberian $4 \mathrm{~mL}$ pepton $5 \%$ adalah $0,8^{\circ} \mathrm{C}$, dan pada pemberian $5 \mathrm{~mL}$ pepton $5 \%$ adalah $0,8^{\circ} \mathrm{C}$. Semua hewan uji yang mengalami peningkatan suhu tubuh sebesar atau sama dengan $0,6^{\circ} \mathrm{C}$ dapat dikategorikan demam. Pada hasil penelitian ini didapatkan bahwa suhu hewan coba lebih dari $0,6^{\circ} \mathrm{C}$ pada suhu rektal sehingga dapat dikatakan hewan uji coba mencapai demam, oleh karena itu dipilih yang mendekati dengan $0,6^{\circ} \mathrm{C}$ yaitu $3 \mathrm{~mL}$.

Pada tahapan ini tikus akan mengalami fase demam, berdasarkan uji pendahuluan yang telah dilakukan waktu yang optimal ketika tikus dalam keadaan demam adalah satu jam dan yang digunakan pepton $5 \%$ sebanyak 3 mL/ekor. Sehingga pada keadaan tersebut tikus segera diberikan 
bahan uji berupa suspensi ekstrak daun sisik naga, suspensi parasetamol, dan suspensi Na-CMC $1 \%$ sesuai dengan kelompoknya masing - masing.

Data hasil penghitungan suhu rektal tikus sesudah diberi perlakuan pemberian suspensi ekstrak daun sisik naga (Pyrrosia piloselloides (L.) M.G. Price) pada beberapa perlakuan dapat dilihat pada (gambar 1). Berdasarkan gambar 1 bahwa rata - rata suhu rektal tikus demam dalam kurun waktu 30 menit setelah pemberian perlakuan berkisar antara $37,1-37,8{ }^{\circ} \mathrm{C}, 60$ menit rata rata suhu rektal tikus demam berkisar antara $37,04-37,28{ }^{\circ} \mathrm{C}, 90$ menit sesudah pemberian perlakuan rata - rata suhu rektal tikus demam berkisar antara $37,0-37,14{ }^{\circ} \mathrm{C}$, menit ke 120 berkisar antara $36,92-37,02{ }^{\circ} \mathrm{C}$, menit ke 150 berkisar antara $36,9-36,98{ }^{\circ} \mathrm{C}$, menit 180 rata - rata suhu rektal tikus berkisar antara $36,9-36,98{ }^{\circ} \mathrm{C}$, menit ke 210 berkisar antara $36,94-36,98{ }^{\circ} \mathrm{C}$, menit 240 berkisar antara $36,96-36,98{ }^{\circ} \mathrm{C}$.

Data rata-rata suhu rektal tikus pada pemberian perlakuan suspensi ekstrak daun sisik naga (Pyrrosia piloselloides L.), suspensi parasetamol, suspensi Na-CMC, pepton 5\% dan suhu awal dapat dilihat pada gambar diagram garis.

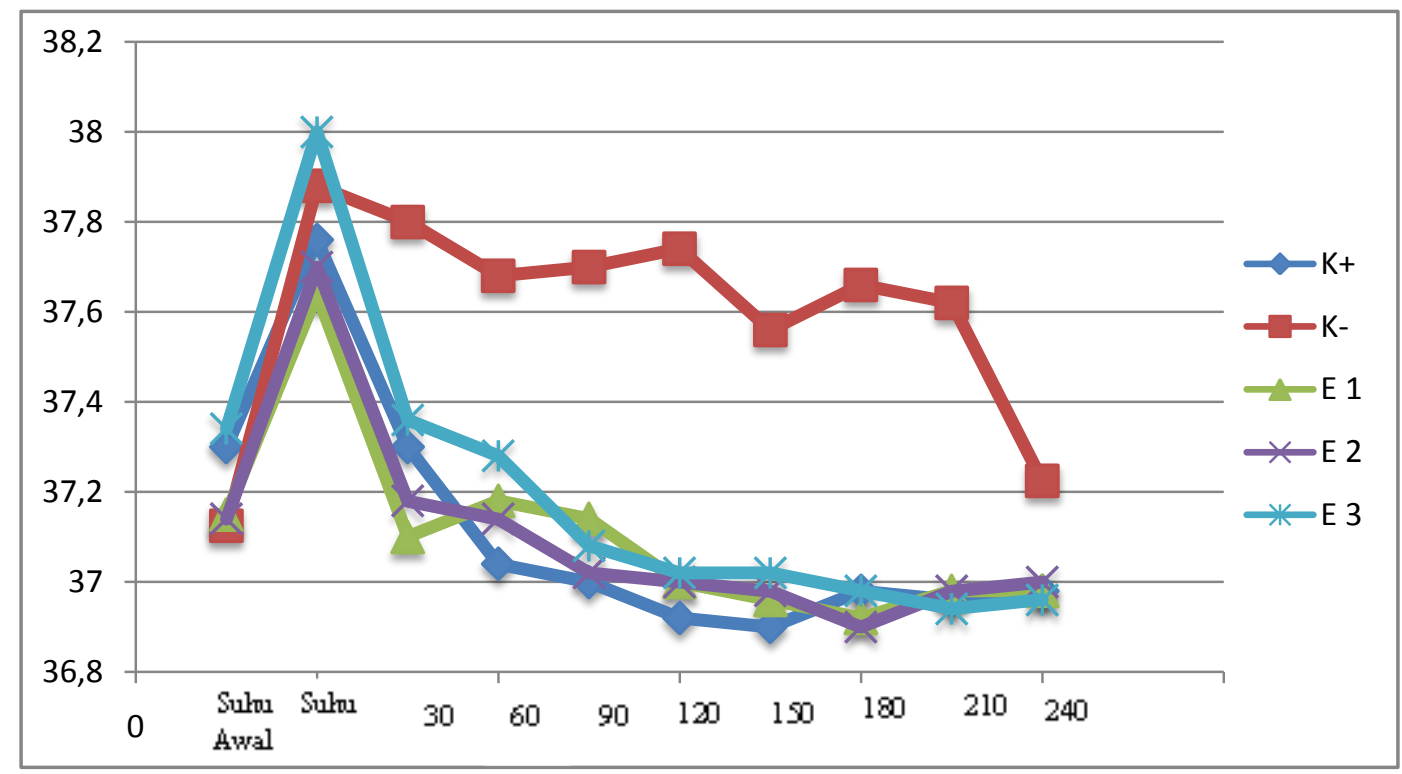

Gambar 1. Diagram Garis Rata - rata Suhu Rektal Tikus Sebelum dan Sesudah PemberianPerlakuan

Sebelum dilakukan analisis statistik menggunakan ANOVA terlebih dahulu dilakukan perhitungan persen daya antipiretik dengan menggunakan rumus (t0 - t60)/(t0-tawal) x $100 \%$. Perhitungan menggunakan t60 dikarenakan pada waktu 60 menit merupakan waktu yang optimal dalam mencapai puncak penurunan suhu demam pada rektal tikus. Adapun rata - rata dari persen daya antipiretik dapat dilihat pada table II.

Tabel II. Rata - Rata Persen Daya Antipiretik

\begin{tabular}{ll}
\hline Kelompok & $\begin{array}{l}\text { \%Daya } \\
\text { Antipiretik }\end{array}$ \\
\hline Suspensi Parasetamol & $159,32 \pm 26,60$ \\
\hline
\end{tabular}




\begin{tabular}{llllll}
\hline \multicolumn{2}{l}{ Suspensi Na-CMC } & & & & $24,14 \pm 15,69$ \\
\hline $\begin{array}{l}\text { Suspensi } \\
\mathbf{0 , 0 6 2 \%}\end{array}$ & ekstrak & daun & sisik & naga & $97,32 \pm 19,23$ \\
\hline $\begin{array}{l}\text { Suspensi } \\
\mathbf{0 , 1 2 5 \%}\end{array}$ & ekstrak & daun & sisik & naga & $100,00 \pm 0,00$ \\
\hline $\begin{array}{l}\text { Suspensi } \\
\mathbf{0 , 2 5 \%}\end{array}$ & ekstrak & daun & sisik & naga & $118,32 \pm 48,72$ \\
\hline
\end{tabular}

Data yang di peroleh selanjutnya di lakukan uji menggunakan Analisis Varian (ANOVA). Hasil analisis varian yang dilakukan adalah untuk mengoreksi atau membandingkan ada atau tidaknya perbedaan pada pemberian perlakuan. Berdasarkan hasil Analisis Varian (ANOVA) menunjukkan bahwa pemberian pepton 5\% sebanyak $3 \mathrm{~mL} /$ ekor secara subkutan memberikan hasil yang signifikan $(\mathrm{p}<0,05)$ dalam meningkatkan suhu rektal tikus demam, sedangkan pada pemberian suspensi ekstrak daun sisik naga yang di uji dengan menggunakan analisis varian (ANOVA) memberikan hasil yang signifikan dalam menurunkan suhu rektal tikus demam.

Pada uji lanjutan ANOVA menunjukkan bahwa pemberian suspensi ekstrak daun sisik naga memberikan hasil yang signifikan dalam menurunkan suhu rektal tikus. Dari uji ANOVA pada rata - rata suhu rektal tikus diperoleh nilai $\mathrm{F}$ hitung menit 240 adalah 32,556 dengan tingkat signifikan 0,05. Jika dibandingkan dengan $\mathrm{F}$ tabel, perhitungan pada V1 menggunakan jumlah varian (perlakuan) dikurangkan $1(5-1=4)$ diperoleh nilai 4 dan nilai V2 diperoleh dengan menggunakan jumlah sampel (250) dikurangkan jumlah varian (5), sehingga diperoleh nilai 245. Pada titik inilah diperoleh $\mathrm{F}$ tabel bernilai 2,408, sehingga $\mathrm{F}$ hitung lebih besar dari $\mathrm{F}$ tabel $(32,556>2,408)$ dan hipotesis yang diterima adalah HI yaitu ekstrak daun sisik naga mempunyai aktivitas antipiretik.

Uji lanjutan yang digunakan adalah LSD (Least significant different). Uji LSD digunakan untuk melihat apakah setiap perlakuan yang dilakukan memiliki perbedaan yang bermakna atau tidak bermakna dan juga untuk melihat perlakuan mana yang memberikan efek paling kecil dan efek yang paling besar.

Dari data analisis statistik LSD (Least significant different) didapatkan bahwa antara kontrol positif (suspensi parasetamol) dengan kontrol negatif (suspensi Na-CMC) terdapat adanya perbedaan bermakna $\mathrm{p}<0,05$ dan antara kontrol positif (suspensi parasetamol) dengan perlakuan suspensi ekstrak daun sisik naga $0,062 \%, 0,125 \%, 0,25 \%$ terdapat perbedaan tidak bermakna $\mathrm{p}>0,05$. Berdasarkan data hasil penghitungan statistik dapat disimpulkan bahwa ekstrak daun sisik naga (Pyrrosia piloselloides (L.) M.G. Price) memiliki aktifitas antipiretik dengan penginduksi pepton 5\%.

Demam mengacu pada peningkatan suhu tubuh sebagai akibat dari infeksi atau peradangan, sebagai respon terhadap invasi mikroba, sel - sel darah putih mengeluarkan zat kimia berupa pirogen endogen. Pirogen meningkatkan pada titik patokan termostat hipotalamus selama demam dengan memicu pengeluaran lokal prostaglandin, yaitu zat perantara kimiawi lokal yang bekerja langsung di hipotalamus.

Salah satu senyawa yang dapat menghambat pengeluaran prostaglandin adalah flavonoid. Flavonoid merupakan salah satu senyawa yang terdapat pada daun sisik naga (Pyrrosia piloselloides (L.) M.G. Price). Flavonoid dapat menghambat prostaglandin, proteinkinase, monoaminoksidase, DNA polymerase dan siklooksigenase (Kohli et. al., 2005). Penghambatan pada enzim siklooksigenase terutama siklooksigenase - $2(\mathrm{COX}-2)$ dapat memberikan pengaruh lebih luas oleh karena mekanisme penghambatan enzim siklooksigenase merupakan langkah awal untuk menuju jalur hormon eikosanoid yang merupakan zat aktif biologik yang berasal dari asam arakhidonat seperti tromboksan dan prostaglandin (Indah, 2004). Mekanisme penghambatan pada prostaglandin akan menurunkan titik thermostat tubuh di hipotalamus sehingga demam menjadi turun (Rakayudha, 2010). 
Menurut Daniele (2008)senyawa flavonoid juga berfungsi sebagai antioksidan yang bekerja sebagai inhibitor biosintesis prostaglandin. Senyawa flavonoid bekerja pada endothelium mikrovaskular untuk menghambat pelepasan asam arakhidonat dan sekresi enzim lisosom dari membran dengan jalan memblok jalur siklooksigenase dan jalur lipoksigenase sehingga menurunkan kadar prostaglandin dan leukotriena (mediator inflamasi) (Indah, 2004).

\section{KESIMPULAN}

Berdasarkan penelitian yang telah dilakukan maka dapat disimpulkan bahwa ekstrak daun Sisik Naga (Pyrrosia piloselloides (L.) M.G Price) mempunyai aktivitas antipiretik terhadap tikus putih (Rattus norvegicus) jantan galur wistar yang diinduksi pepton 5\% dan pada konsentrasi $0,25 \%$ memilki aktivitas antipiretik terhadap tikus putih (Rattus norvegicus) jantan galur wistar.

\section{UCAPAN TERIMA KASIH}

Peneliti mengucapkan terimakasih kepada Akademi Farmasi Yarsi Pontianak atas semua kontribusinya selama penelitian berlangsung dan dalam penyusunan artikel jurnal ini.

\section{DAFTAR PUSTAKA}

Anief, M. 1995. Ilmu Meracik Obat. Yogyakarta:Gadjah Mada University Press.

Ansel, H. C. 1989. Pengantar Bentuk Sediaan Farmasi. Jakarta: UI Press.

Dalimarta, S. 2000. Atlas Tumbuhan Obat Indonesia. Jilid II. Jakarta: Pustaka Pembangunan Swadaya Nusantara.

Depkes RI. 1995. Farmakope Indonesia, Edisi IV. Jakarta: Departemen Kesehatan Republik Indonesia.

Hariana, A. 2006. Tumbuhan Obat dan Khasiatnya. Jakarta: Penebar Swadaya.

Hariyanto, W. 1995. Mengapa Kita Demam. Jakarta: Arcan.

Ibrahim, N., Yusriadi, Ihwan. 2014. UjiAntipiretik Kombinasi Ekstrak Etanol Herba Sambiloto (Andrographis paniculata Burm.f.Ness.) dan Ekstrak Etanol Daun Belimbing Wuluh (Averrhoa bilimbi L.) pada Tikus Putih Jantan (Rattus norvegicus). Palu: Jurusan Farmasi, Fakultas Mipa, Universitas Tadulako. Online Jurnal of Natural Science, Vol.3(3):257-268

Indah, M. 2004. Mekanisme Kerja Hormon. Fakultas Kedokteran Bagian Biokimia Universitas Sumatera Utara.

Kohli, K, Ali, J., Ansari, M.J., dan Reheman, Z. 2005. Curcumin: A Natural Antiinflammatory Agent. Indian J. Pharmacol

Mutschler, Ernst. 1986. Dinamika Obat Farmakologi dan Toksikologi. Edisi Kelima. Bandung: Institut Teknologi Bandung.

Simoni, Daniele., et al. 2008.Antitumor Effects of Curcumin and Structurally B-Diketone Modified Analogs on Multidrug Resistant Cancer Cells. Bioorganic and Medicinal Chemistry Letter, Volume 18, Issue 2, Pages 845-849

Styawan, A. A., Budiman, H. 2015. Pengaruh Penurunan Dosis Dari Ekstrak Batang Brotowali (Tinospora crispa, L.) Terhadap Efek Antipiretik Pada Tikus Putih Jantan Galur Wistar. CERATA Journal Of Pharmacy Science.

Tamsuri, A. 2007. Tanda - tanda Vital Suhu Tubuh. Hal 27. Buku Kedokteran Jakarta: EGC. 